\section{Protein detection sensitivity}

I have been trying to find the answer to the following question online to no avail and wondered if Vital might be able to help.

What I would really like to know is exactly what level of protein detection sensitivity is required to comply with HTM 01-05 regulations in relation to protein residue tests for bench top dental ultrasonic cleaners. For example, does the protein detection sensitivity level need to be below 3 ug or would a level of protein detection sensitivity level of 50 ug suffice?

\section{Barbara Watson \\ Dental Nurse}

Professor Andrew Smith, Consultant

Microbiologist, Glasgow Dental Hospital \& School responds: I assume that this query relates to the weekly periodic test requirement for sonic baths (HTM 01-05 section 14.3). I would point out firstly that it would be prudent to ensure that the ultrasonic bath has passed its validity or performance qualification tests relating to ultrasonic activity and cleaning efficacy (correct test soil and load used?) on installation (these tests vary enormously in quality between testers).

The reference to the protein residue test is $B S$ EN ISO 15883-1 (year unspecified) and three tests are specified - ninhydrin, OPA and biuret. I'm not sure what tests Ms Watson is using. The most common one is probably the ninhydrin with a claimed sensitivity of $2 \mathrm{mg} / \mathrm{m} 2$ - again lack of details from the query (sensitivity relative to surface area) makes it difficult to provide a relevant response. To put this into context, in our BDJ paper ${ }^{1}$ using a laboratory method of extraction and assaying - scalers typically had 30 ug per instrument residual after cleaning.

I think the best you can do at the moment is to ensure correct installation of the ultrasonic bath, undertake the prescribed periodic training (there are some papers out there that have compared different methods but I don't have these to hand), operate the bath with the recommended detergent, change solutions frequently, rinse in purified water after cleaning, dry and visually inspect instruments with an illuminated magnifier to ensure no large residues left behind and keep appropriate records. I'm sceptical that the currently marketed protein residue tests for use in dental practice have a reliable sensitivity and specificity.

If someone was prepared to fund some research into this we would happily accommodate!

\section{Vassey M, Budge C, Poolman T et al. A} quantitative assessment of residual protein levels on dental instruments reprocessed by manual, ultrasonic and automated cleaning methods. $\mathrm{Br}$ Dent J 2011; 210: E14.

Barbara replies: Brilliant! This has given me enough information to formulate a course of action - many thanks.

\title{
WIN! TICKETS TO GRAND DESIGNS LIVE BIRMINGHAM
}

Grand Designs Live, the UK's top

contemporary home show, will be at the

NEC in Birmingham from 12-14 October

2012. Based on the hugely popular Channel 4

series presented by Kevin McCloud, the show

offers visitors a unique opportunity to see

all the latest trends for the home. With over

500 exhibitors, you can shop from a great

selection of brands with hundreds of items not available on the high street.

Vital has teamed up with Grand Designs Live and has ten pairs of tickets to give away. If you would like to win a pair of tickets, just send your name, address and job title to vitaleditorial@nature.com or Vital Editorial, NPG, 4-6 Crinan Street, London N1 9XW by 8 October 2012, or send a message on www. facebook.com/vitalmagazine.

If you're aren't lucky enough to win, you can still get two standard tickets for the price of one - visit www.granddesignslive. com and enter the code VITAL12 to claim your discount, or telephone 08448541348 (transaction fee $£ 1.70$ per order and tickets must be booked in advance). Offer ends 12 October 2012.

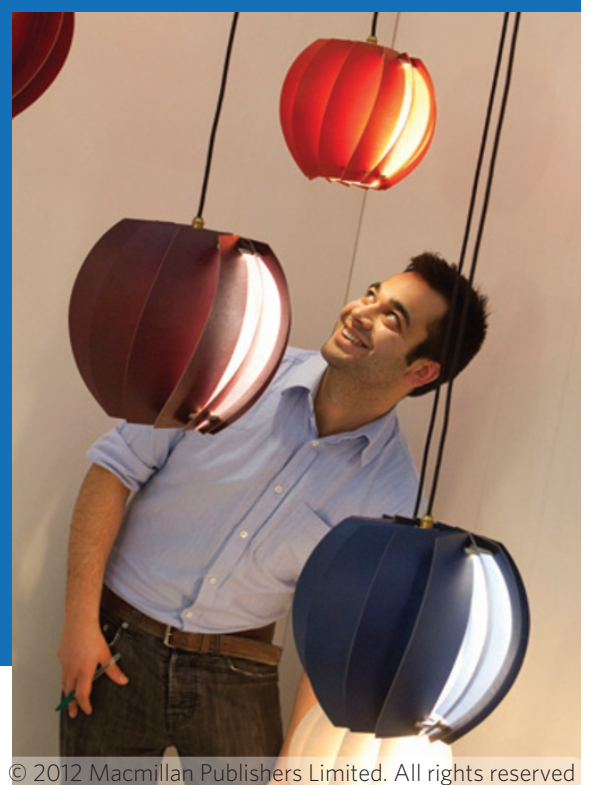

\section{Corrections}

- In her letter $A$ new category of hygienist (Vital summer 2012 page 4), the author Helen Parkin would like to point out that she had not intended to say that she was a specialist in advanced non-surgical periodontal

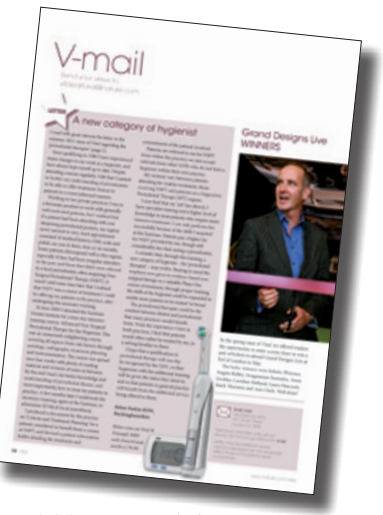
therapy. The letter should have read: '...I have specialised training and a higher level of knowledge to treat patients who require more intensive treatment.'

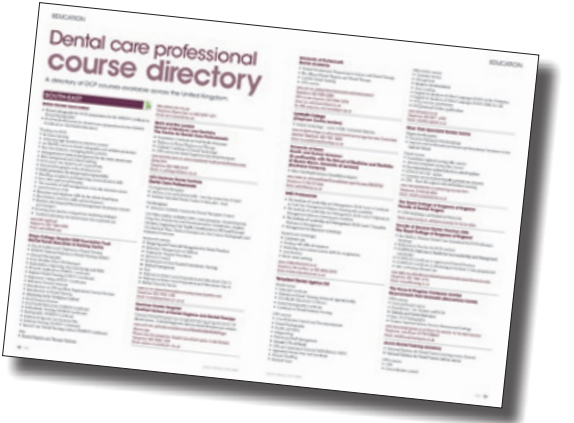

- The course directory listing for NHS Ayrshire and Arran in the Dental care professional course directory (Vital summer 2012 page 18) gave incorrect contact details. The correct telephone number is 01294 323457 and the correct email address is susan.mcgregor1@nhs.net.

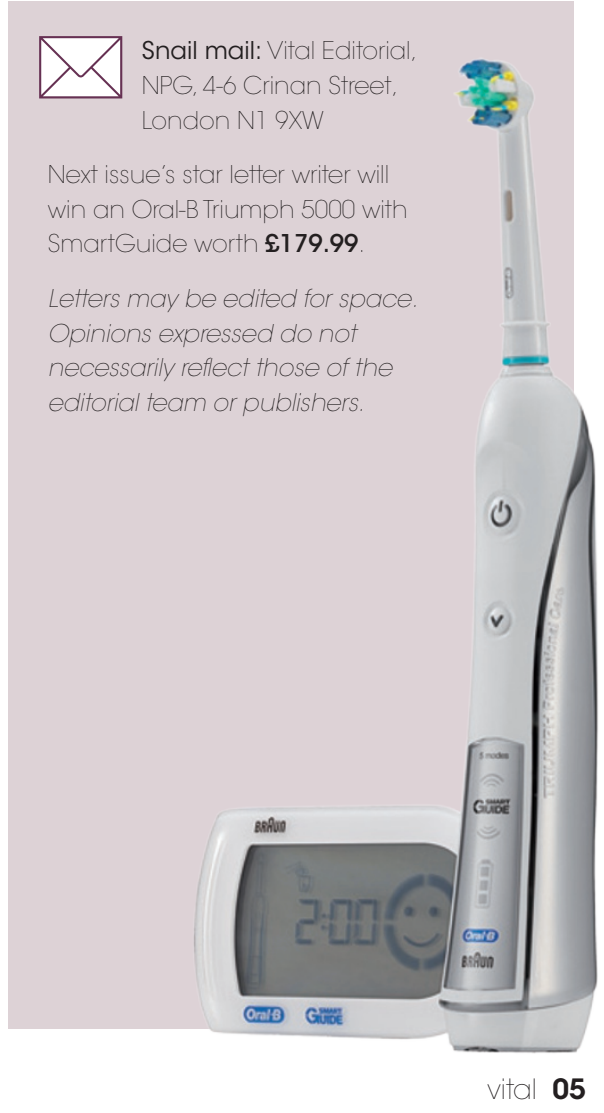

